\title{
PENGOPERASIAN RUMPON ELEKTRONIK PADA ALAT TANGKAP BAGAN DI PULAU LANCANG KEPULAUAN SERIBU JAKARTA
}

\author{
ELECTRONIC FISH AGGREGATING DEVICE OPERATION ON LIFT NET IN \\ LANCANG ISLAND, THOUSAND ISLAND, JAKARTA \\ Roza Yusfiandayani ${ }^{1}$, Indra Jaya ${ }^{2}$, Arif Baswantara ${ }^{2}$ \\ ${ }^{1}$ Departemen Pemanfaatan Sumberdaya Perikanan \\ ${ }^{2}$ Departemen Ilmu dan Teknologi Kelautan \\ Fakulltas Perikanan dan Ilmu Kelautan, Institut Pertanian Bogor \\ Korespondensi : ochaipb@gmail.com,indrajaya123@gmail.com
}

\begin{abstract}
Electronics FADs is an innovative fishing tools tha thave the same function as in the general FADs to attract and collect fish. The trial of electronic FADs was did at liftnet gear, in purpose to see the performance of these tools. Effectiveness of use electronic FADs analysis from catch harvest. Electronic FADs has attractor a light (LED, 5 Watts) and sound $(10-1000 \mathrm{~Hz}, 1-20 \mathrm{kHz}$ and $20-100 \mathrm{kHz}$ ) with a voltage source of 12 volt battery. Installation ofelectronic FADs in the trial following the existing catch method in the liftnet. Based on catches, electronic FADs managed to collectan average of $4.60 \mathrm{~kg}$ if time installation is an hour, and collect an average of $4.07 \mathrm{~kg}$ if time installation is 30 minute. Electronic FADs work well, attractor is able to function through out the trial and managed toc ollectt he fish, but when compared the effective ness of the catch to the liftnet, then the use of electronic FADs in the liftnet is still not effective. Suggestions for improving the effectiveness ofelectronic FAD scatchon the liftnet is increase the intensity and power on light attractor, and deeper study of the sounds frequency which response by fish.
\end{abstract}

Keywords: catch, effectiveness, electronic Fish Agregating Device, lift net

\begin{abstract}
ABSTRAK
Rumpon Elektronik merupakan inovasi alat bantu penangkapan ikan yang memiliki fungsi sama seperti rumpon pada umumnya yaitu untuk memikat dan mengumpulkan ikan. Uji coba rumpon elektronik ini dilakukan pada alat tangkap bagan, dengan tujuan untuk melihat kinerja dari alat tersebut. Efektivitas penggunaan rumpon elektronik dianalisis dari hasil tangkapannya. Rumpon elektronik ini memiliki atraktor berupa cahaya (LED, 5 Watt) dan suara (10-1000 Hz, 1-20 $\mathrm{kHz}$ dan 20-100 kHz) dengan sumber tegangan berupa aki 12 volt. Pemasangan rumpon elektronik dalam uji coba mengikuti metode penangkapan yang ada di bagan. Berdasarkan jumlah hasil tangkapan, rumpon elektronik berhasil mengumpulkan rata-rata $4.60 \mathrm{~kg}$ jika lama waktu pemasangan satu jam, dan mengumpulkan rata-rata $4.07 \mathrm{~kg}$ jika lama waktu pemasangan setengah jam. Rumpon elektronik bekerja dengan baik, atraktor mampu berfungsi selama uji coba dan berhasil mengumpulkan ikan, namun jika dibandingkan tingkat efektivitas hasil tangkap dengan bagan, maka penggunaan rumpon elektronik di bagan masih belum efektif. Saran untuk meningkatkan efektivitas hasil tangkap rumpon elektronik pada bagan yaitu dengan menambah intensitas dan daya pada atraktor cahaya, serta adanya kajian lebih dalam terhadap frekuensi suara yang direspon oleh ikan.
\end{abstract}

Kata kunci: bagan, efektivitas, rumpon elektronik, tangkapan

\section{PENDAHULUAN}

\section{Latar Belakang}

Ketersediaan modal, sarana dan keterampilan yang dimiliki oleh nelayan sangat berpengaruh pada kegiatan perikanan tangkap. Modal yang besar, sarana yang memadai dan nelayan yang terampil akan memiliki jangkauan area penangkapan yang lebih luas dibandingkan dengan nelayan yang memiliki keterbatasan modal dan sarana. Hal ini juga berdampak pada hasil tangkapan dan pendapatan mereka, sehingga dibutuhkan alternatif lain untuk membantu membatasi kendala keterbatasan tersebut. Salah satu alternatif yang dapat ditempuh adalah menerapkan teknologi rumpon atau biasa dikenal juga dengan sebutan Fish Aggregating Device (FAD) (Yusfiandayani 2004).

Bagian atraktor rumpon tradisional pada umumnya terbuat dari pelepah daun kelapa atau rongsokan becak yang ditenggelamkan. Jenis rumpon tradisional ini umumnya hanya menggunakan satu 
atraktor dan cenderung memiliki selektivitas target yang rendah. Daya tahan rumpon tradisional juga terbatas seperti daun kelapa yang cepat lapuk dan terbawa oleh arus laut (IMI 2012). Keterbatasan yang dimiliki oleh rumpon tradisional ini memunculkan ide untuk membuat rumpon yang lebih selektif dan tahan lama yang mampu membantu memaksimalkan hasil tangkapan dan mampu mengikuti perkembangan teknologi. Tingkah laku ikan yang tertarik dengan cahaya dan suara mampu diterapkan dalam ide pembuatan rumpon ini. Alat ini diberi nama rumpon elektronik.

Tujuan penelitian ini adalah mendeskripsikan struktur bangun dan sistem kerja alat rumpon elektronik serta hasil uji coba langsung pada alat tangkap bagan. Membandingkan efektifitas hasil tangkapan dari penggunaan rumpon elektronik pada bagan dengan hasil tangkapan yang bisa diperoleh oleh bagan itu sendiri.

\section{METODE PENELITIAN}

Penelitian ini dilakukan di workshop dan watertank laboratorium akustik Departemen Ilmu dan Teknologi Kelautan, Fakultas Perikanan dan Ilmu Kelautan, Institut Pertanian Bogor dan Pulau Lancang, Kepulauan Seribu.

\section{Desain konstruksi rumpon elektronik}

Rumpon elektronik (Gambar 1) dengan rumpon tradisional memiliki perbedaan pada bagian atraktor. Atraktor pada rumpon tradisional yang berupa daun-daunan diubah menjadi cahaya dan suara. Berikut desain konstruksi rumpon elektronik.

\section{Uji coba laboratorium lapang}

Uji coba laboratorium meliputi kinerja sistem secara fungsional yaitu berupa pembangkitan cahaya dan pembangkitan gelombang suara. Uji coba kedap air terhadap keseluruhan sistem. Uji coba kedap air ini bertujuan untuk membuat sistem yang dapat bekerja dengan aman di dalam air.

Uji coba lapang rumpon elektronik dilakukan dengan tiga perlakuan yang dibedakan pada bagian frekuensi suara yang digunakan. Frekuensi-frekuensi yang digunakan adalah $10-1000 \mathrm{~Hz}, 1-20 \mathrm{kHz}$, dan 20-100 kHz. Perlakuan dengan tiga kisaran frekuensi ini didasarkan pada tiga tipe suara yaitu infrasonik, suara biasa dan ultrasonik. Cahaya yang digunakan adalah tetap yaitu LED dengan daya $5 \mathrm{~W}$ dengan cahaya warna putih. Kedalaman rumpon elektronik ditempatkan pada kedalaman 3-5 meter dengan kedalaman perairan 14 meter. Teknis uji coba lapang yang dilakukan dapat dilihat pada Tabel 1 .

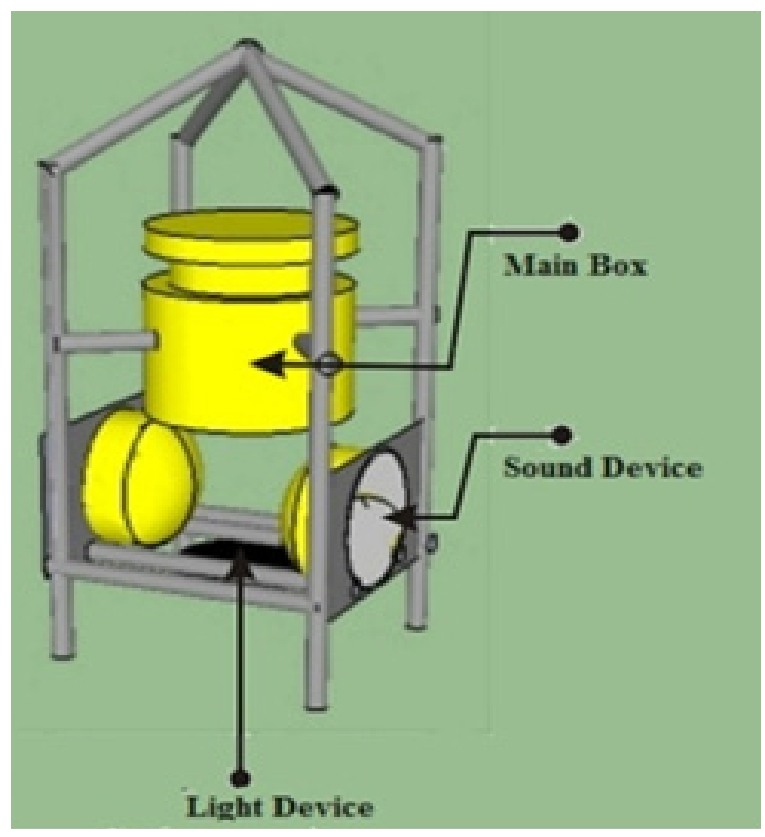

Sumber: Jaya 2007

Gambar 1. Desain Rumpon Elektronik 
Tabel 1. Teknis uji coba lapang rumpon elektronik

\begin{tabular}{lll}
\hline \multicolumn{1}{c}{ Perlakuan } & $\begin{array}{c}\text { Waktu dilakukan } \\
\text { (malam ke-) }\end{array}$ & Pukul (WIB) \\
\hline Atraktor suara frekuensi $10-1000 \mathrm{~Hz}$ & $1,4,8$ & $19: 00-01: 00$ \\
Atraktor suara frekuensi $1000-20.000 \mathrm{~Hz}$ & $2,5,6,10$ & $19: 00-01: 00$ \\
Atraktor suara frekuensi $20.000-100.000 \mathrm{~Hz}$ & $3,7,9$ & $19: 00-01: 00$ \\
\hline
\end{tabular}

\section{HASIL DAN PEMBAHASAN}

\section{Uji coba laboratorium}

Uji coba laboratorium dilaksanakan pada tanggal 14 Februari 2013 di watertank laboratorium akustik Departemen Ilmu dan Teknologi Kelautan, Fakultas Perikanan dan Ilmu Kelautan, Institut Pertanian Bogor. Rumpon elektronik mulai dipasang pada pukul 12:11 WIB pada kedalaman 2 meter dan diangkat pada pukul 20:24 WIB. Selama uji coba, sistem elektronik dari atraktor lampu dan cahaya mampu bertahan dengan baik, namun pada Main Box terdapat sedikit kebocoran yang diperkirakan akibat dari kurang kuatnya pemasangan tutup Main Box.

\section{Analisis alat kerja}

Rumpon Elektronik dibuat sesuai dengan desain yang ada pada Gambar 2 . Kerangka rumpon terbuat dari Stainless Steel 104, dengan Main Box dan Speaker Cover terbuat dari DOP PVC. Berikut tampak dari Rumpon Elektronik yang diuji coba.

Rumpon Elektronik ini memiliki dimensi tinggi total $86 \mathrm{~cm}$, lebar total 30 $\mathrm{cm}$ dan panjang total $30 \mathrm{~cm}$, dengan tinggi Main Box 24 inci dan diameter 8 inci. Sumber tegangan berupa aki 12 volt, dengan atraktor suara berupa speaker Audax 4 inci dan atraktor cahaya berupa LED 5 watt.

\section{Analisis daya pikat atraktor suara}

Atraktor suara mampu berfungsi dengan baik selama uji coba lapang. Pengeras suara yang digunakan mampu bertahan dengan sangat baik tanpa mengalami kebocoran. Proses pergantian frekuensi dilakukan dengan mengganti file suara yang ada pada Micro SD MP3 player, dan semua sistem ini terus berfungsi hingga akhir uji coba. Analisis daya pikat atraktor suara dan cahaya dilakukan dengan melihat spesies ikan. Berdasarkan spesies yang ditangkap, secara umum tidak jauh berbeda dengan spesies ikan yang biasa ditangkap oleh nelayan bagan, seperti ikan teri, ikan selar, ikan peyek, cumi dan sotong. Akan tetapi pada sejumlah penangkapan yang menggunakan rumpon elektronik, berhasil ditangkap ikan yang jarang didapatkan oleh nelayan bagan biasanya, seperti ikan lidah, ikan kue, dan ikan buntal. (Tabel 2) menunjukkan jenis-jenis hasil tangkapan yang diperoleh beserta nama ilmiah dan frekuensi tertangkapnya jenis tersebut.

\section{Analisis daya pikat atraktor}

Persentase hasil tangkapan berdasarkan jenis ikan yang ditangkap dapat dilihat pada Gambar 3. Persentase hasil tangkapan berdasarkan frekuensi suara yang digunakan pada atraktor dapat dilihat pada Gambar 4, 5 dan 6 .

Kesimpulan pasti mengenai efek dari frekuensi suara yang digunakan sebenarnya belum ditemukan, namun dalam uji coba kali ini didapatkan bahwa pada frekuensi 1000-20.000 Hz sering tertangkap ikan dengan ukuran yang lebih besar dan yang jarang ditangkap oleh nelayan. Ikan lidah dan ikan kue yang seperti yang disebutkan sebelumnya, tertangkap ketika frekuensi suara yang digunakan adalah 1000-20.000 Hz. Akan tetapi untuk hal pengaruh suara dalam proses penangkapan ikan ini sangat perlu dilakukan penelitian lanjutan yang lebih mendalam.

Atraktor cahaya memegang pengaruh yang besar dalam penggunaan rumpon elektronik ini pada alat tangkap bagan. Hal ini dapat dilihat saat lampu yang digunakan mengalami kebocoran, maka pada saat itu juga hasil tangkapan mejadi nihil. Cahaya putih pada lampu yang digunakan memberikan pengaruh pada ikan-ikan kecil.

\section{Analisis hasil tangkapan}

Penggunaan rumpon elektronik ini mendatangkan hasil apabila alat ini berjalan dengan baik. Kejadian hasil tangkapan nihil ketika alat mengalami mati, kebocoran pada lampu dan ketika pemasangan alat ini selama satu setengah jam. Maksimal hasil 
tangkapan diperoleh ketika alat dipasang selama satu jam. Hasil tangkapan terbesar diperoleh pada hari pertama pemasangan yaitu $33 \mathrm{~kg}$. Rumpon dipasang setelah setengah jam lampu bagan dihidupkan. Hasil tangkapan terendah diperoleh kurang dari $1 \mathrm{~kg}$ (Gambar 7 dan 8).

Hasil tangkapan menggunakan lampu bagan memperoleh hasil yang lebih banyak dibandingkan penggunaan rumpon elektronik. Atraktor suara dan cahaya pada rumpon elektronikjuga masih kalah bersaing dengan lampu-lampu bagan yang memiliki intensitas dan daya yang lebih besar. Hal ini menunjukan bahwa penggunaan rumpon elektronik ini pada alat tangkap bagan masih belum efektif.

Penggunaan lampu dengan intensitas dan daya yang besar masih memegang pengaruh lebih pada proses penangkapan di bagan, sehingga pengembangan alat ini selanjutnya bisa dilanjutkan kearah pemaksimalan daya dari setiap atraktornya. Penggunaan rumpon elektronik ini juga belum dicoba pada alat penangkapan ikan lainnya, sehingga belum diketahui efektifitas penggunaan rumpon elektronik ini pada alat penangkapan ikan yang lain.

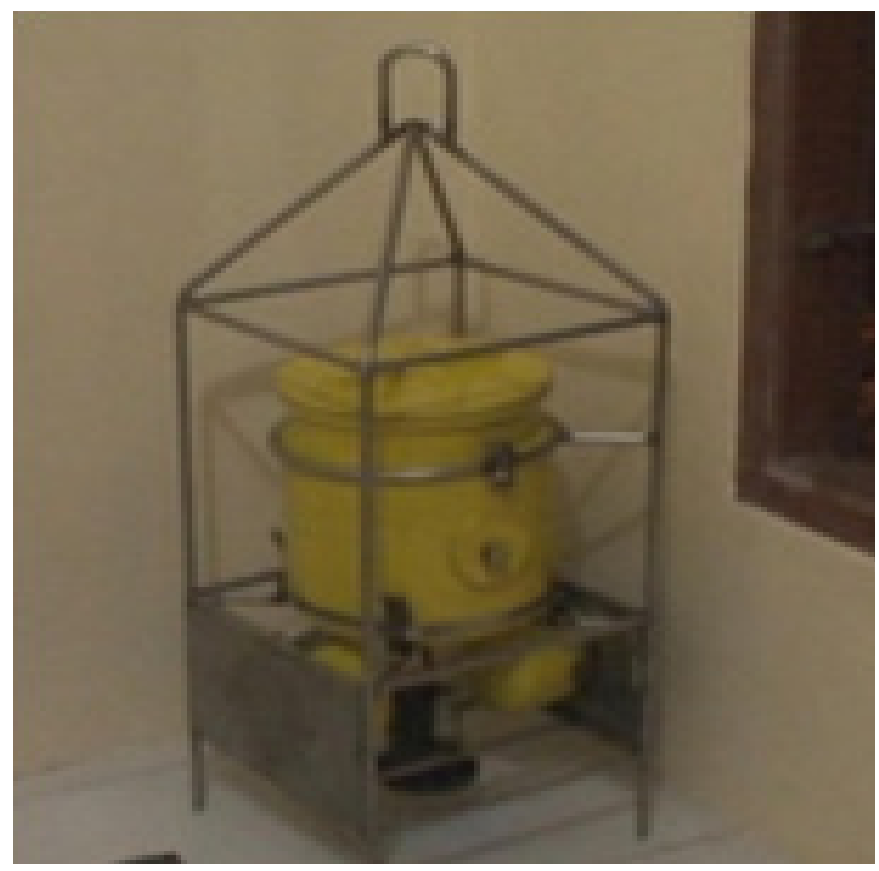

Gambar 2. Rumpon elektronik yang diuji coba

Tabel 2. Nama lokal dan nama ilmiah hasil tangkapan beserta frekuensi tertangkap

\begin{tabular}{clll}
\hline No & \multicolumn{1}{c}{ Nama Lokal } & \multicolumn{1}{c}{ Nama Ilmiah } & Frekuensi Tertangkap \\
\hline 1 & Cumi & Loligo pealei & 15 \\
2 & Teri & Stelophorus indicus & 13 \\
3 & Peyek & Secutor insidiator & 8 \\
4 & Selar & Selaroides leptolepis & 6 \\
5 & Sotong & Sepiasp & 4 \\
6 & Lidah & Cynoglossus bilineatus & 1 \\
7 & Kue & Alectus ciliaris & 1 \\
8 & Tongkol & Auxis rochei & 1 \\
9 & Buntal & Diodon hystrix & 1 \\
\hline
\end{tabular}




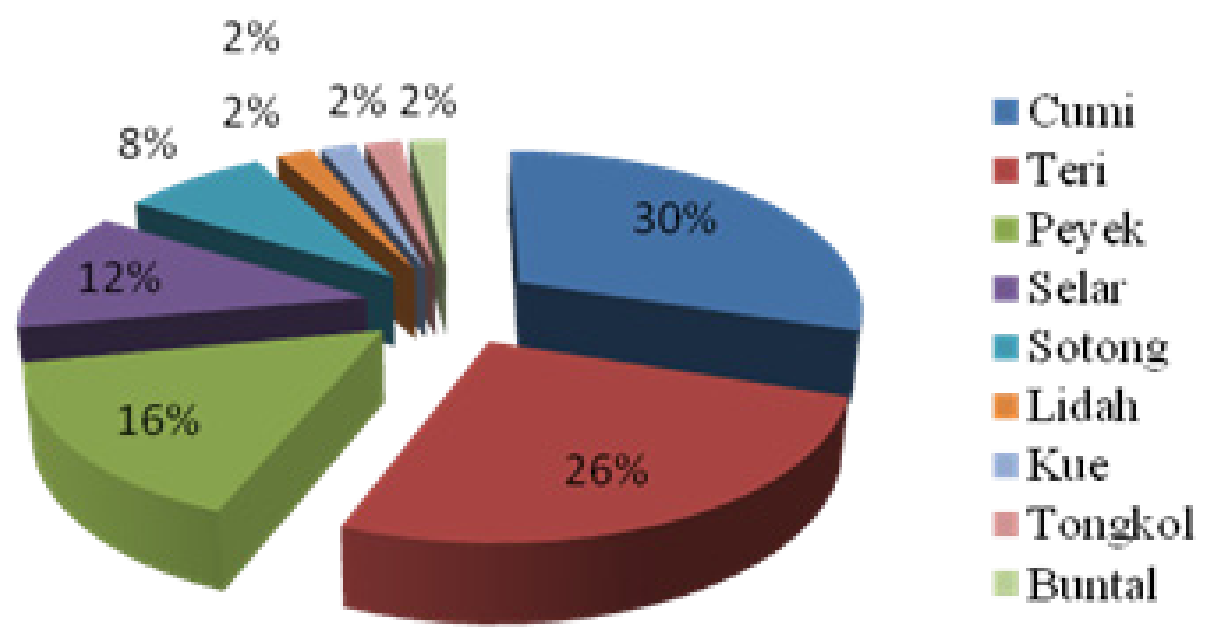

Gambar 3. Persentase hasil tangkapan berdasarkan jenis tangkapan

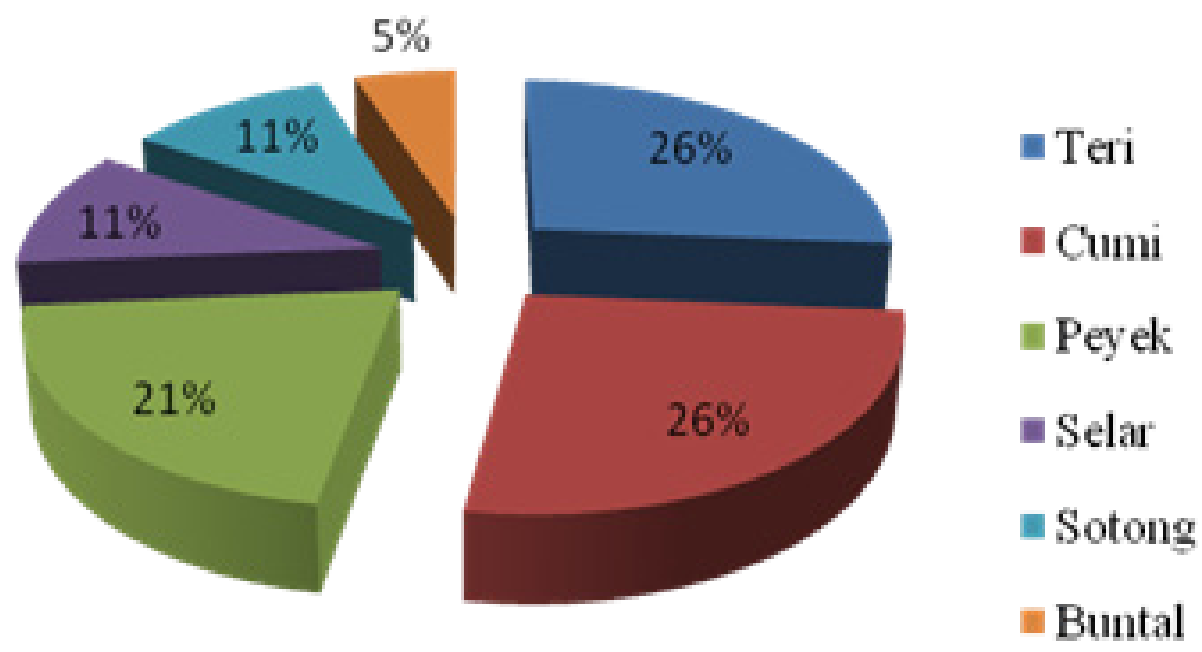

Gambar 4. Persentase jenis hasil tangkapan rumpon elektronik dengan atraktor cahaya dan suara $10-1000 \mathrm{~Hz}$

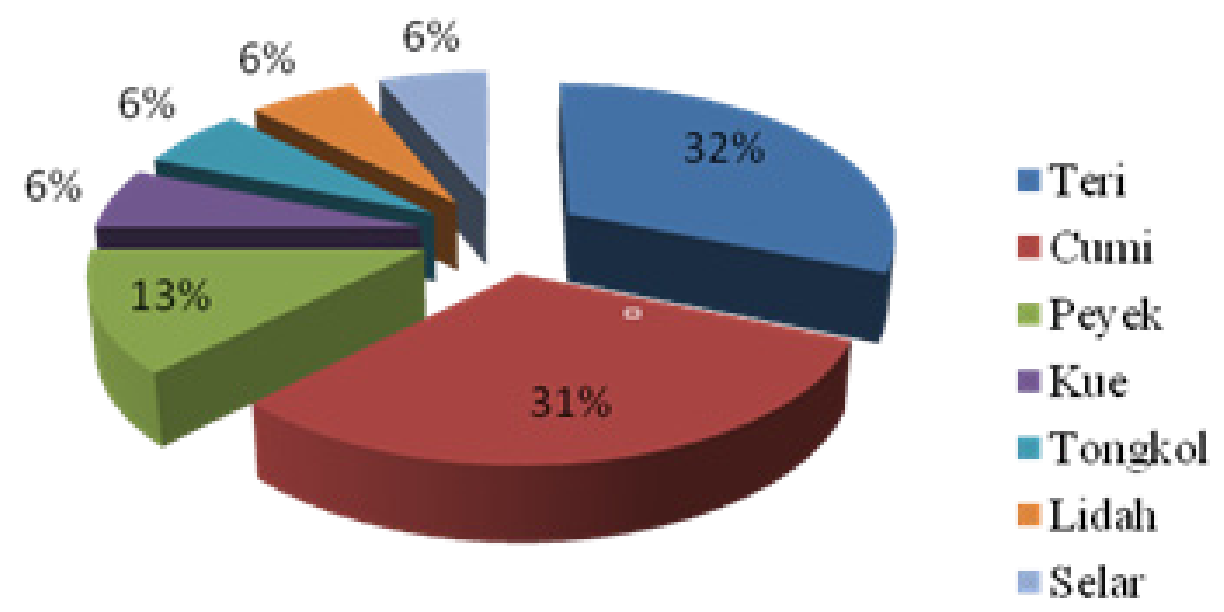

Gambar 5. Persentase jenis hasil tangkapan rumpon elektronik dengan atraktor cahaya dan suara $1000-20.000 \mathrm{~Hz}$ 


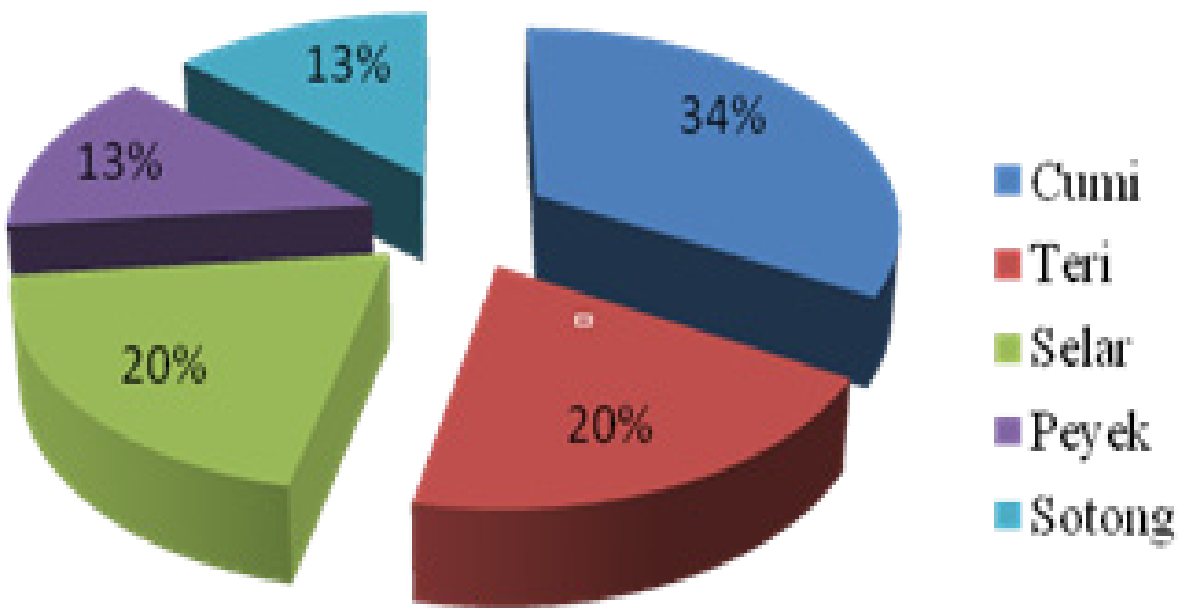

Gambar 6. Persentase jenis hasil tangkapan rumpon elektronik dengan atraktor cahaya dan suara $20000-100.000 \mathrm{~Hz}$

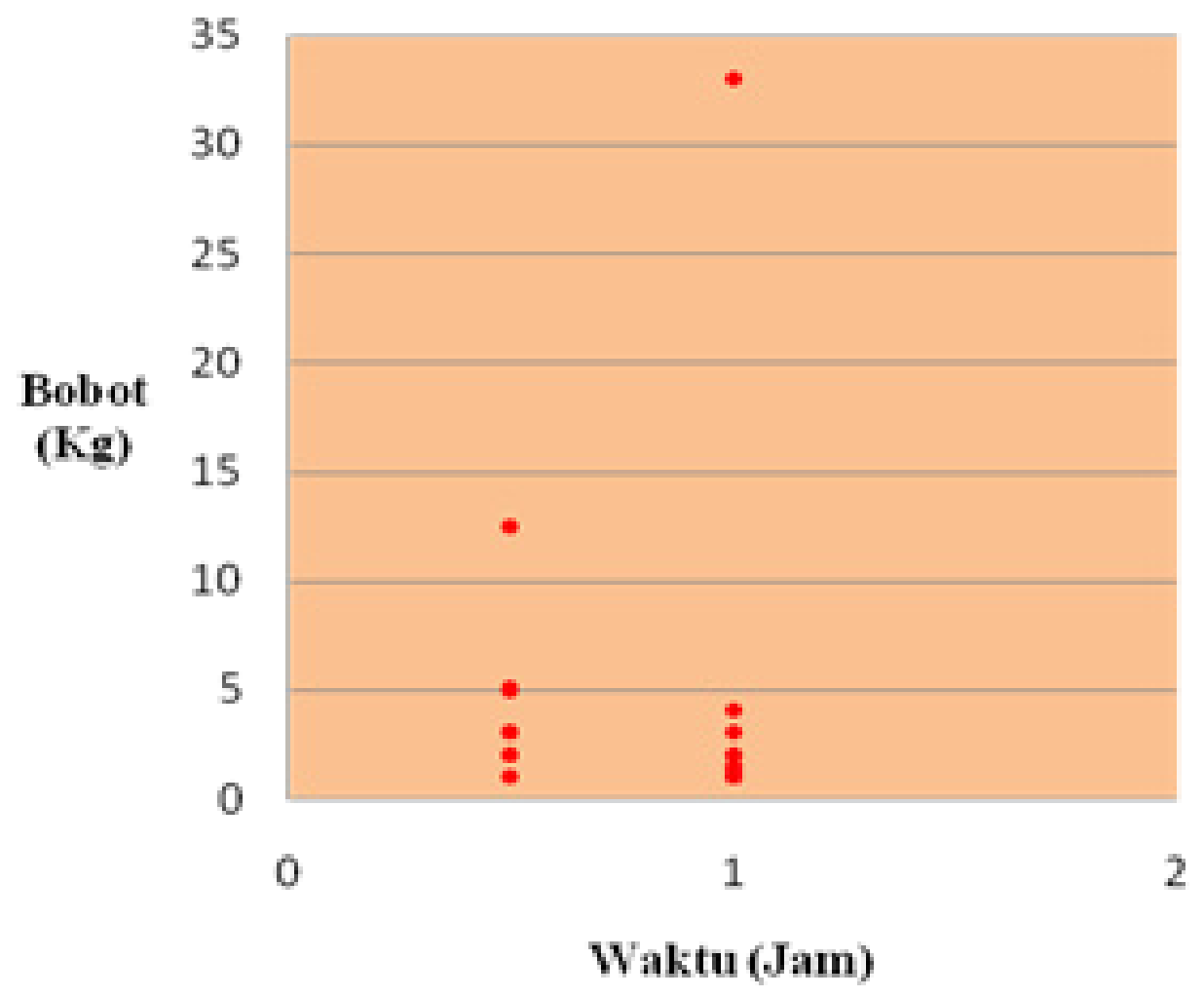

Gambar 7. Grafik bobot hasil tangkapan dengan jam pemasangan menggunakan rumpon elektronik 


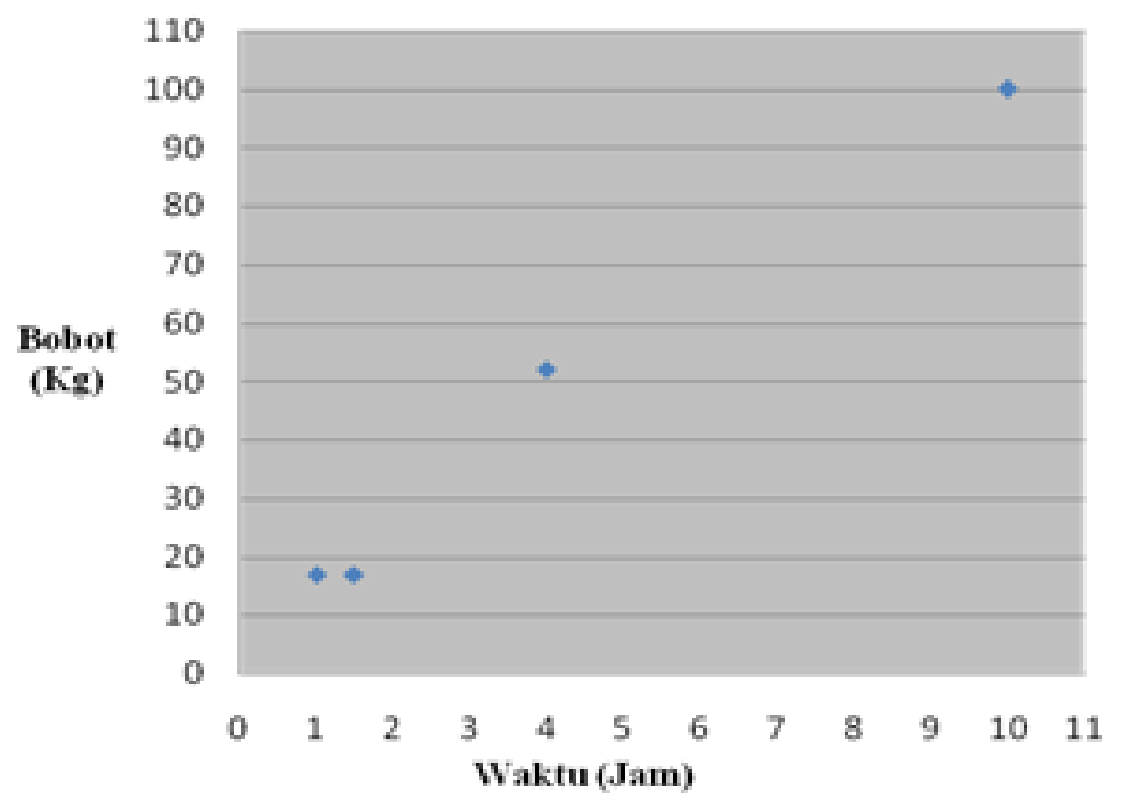

Gambar 8. Grafik bobot hasil tangkapan dengan jam pemasangan menggunakan lampu bagan

\section{KESIMPULAN DAN SARAN}

\section{KESIMPULAN}

Penelitian ini dapat disimpulkan sebagai berikut rumpon elektronik memiliki kerangka stainless steel berbentuk persegi panjang dan limas di atasnya. Memiliki tinggi total $86 \mathrm{~cm}$, lebar total $30 \mathrm{~cm}$ dan panjang total $30 \mathrm{~cm}$. Rumpon elektronik memiliki dua atraktor yaitu cahaya yang berupa lampu LED dan suara yang berupa speaker 4 inci dengan mp3 player sebagai pembangkit suara. Uji coba menunjukkan bahwa sistem rumpon elektronik ini dapat berfungsi dengan baik. Uji coba juga menunjukkan bahwa rumpon elektronik dapat digunakan dalam kegiatan penangkapan ikan, hasil tangkapan dari penggunaan rumpon elektronik memiliki variasi jenis yang serupa dengan hasil tangkapan bagan pada umumnya. Jika dilihat dari jumlah hasil tangkapan, penggunaan rumpon elektronik memiliki rata-rata $5.40 \mathrm{~kg} / \mathrm{jam}$ sedangkan penggunaan lampu bagan memiliki ratarata $11.20 \mathrm{~kg} / \mathrm{jam}$. Hal ini menunjukkan bahwa dalam uji coba, penggunaan rumpon elektronik pada alat tangkap bagan masih belum efektif dalam mengumpulkan ikan daripada penggunaan lampu bagan itu sendiri.

\section{Saran}

Saran yang dapat diberikan dari penelitian ini yaitu uji coba rumpon elektronik selanjutnya dapat dilakukan pada alat penangkapan ikan yang lain seperti purse seine. Uji coba rumpon elektronik selanjutnya juga dapat dilakukan dengan menambahkan perangkat fish finder atau CCTV untuk mengetahui secara pasti waktu yang dibutuhkan rumpon elektronik dalam mengumpulkan ikan, perbaikan pada bagian atraktor cahaya dengan memperbaiki sistem kedap air sehingga lampu yang digunakan dapat lebih kokoh dan tidak mengalami kebocoran, dan perlu adanya penelitian lebih dalam mengenai frekuensi suara yang direspon untuk pengumpulan ikan di laut. Sehingga dapat diprediksi ikan jenis apa yang tertarik dengan selang frekuensi tertentu.

\section{DAFTAR PUSTAKA}

IMI. 2012. Rumpon elektronik, buah tangan IPB untuk nelayan. Indonesia Maritime Institute.

Jaya I. 2007. Laporan teknis rumpon elektronik. Bogor (Tidak Dipublikasikan): Fakultas Perikanan dan Ilmu Kelautan Institut Pertanian 
Bogor.

Tamanyira MM. 2012. Rumpon berkah atau musibah. www.marinebuddies.org. [tanggal akses]

Tim Pengkajian Rumpon Fakultas Perikanan Institut Pertanian Bogor. 1987. Laporan akhir survei lokasi dan desain rumpon di Perairan Ternate, Tidore, Bacan dan Sekitarnya. Bogor (Tidak Dipublikasikan): Laporan Jurusan Pemanfaatan Sumberdaya Perikanan. Fakultas Perikanan Institut Pertanian Bogor.
Von Brandt A. 2005. Fish Catching Method of the Worlds. Edited by Otto G, Klaus L, Erdmann D, Thomas W. London: Blackwell Publishing.

Yusfiandayani R. 2004. Studi tentang mekanisme berkumpulnya ikan pelagis kecil di sekitar rumpon dan pengembangan perikananya di Perairan Pasauran, Propinsi Banten. [Disertasi]. Bogor: Institut Pertanian Bogor. 